\title{
建材の日射透過および反射性能における分光感度特性 \\ A STUDY ON SPECTRAL SENSITIVITY OF SOLAR TRANSMISSION AND REFLECTION PERFORMANCE OF ARCHITECTURAL MATERIALS
}

\author{
一ノ瀬 雅之*, 石野久彌**, 永田明寛*** \\ Masayuki ICHINOSE, Hisaya ISHINO and Akihiro NAGATA
}

\begin{abstract}
This paper presents variations of the solar heat gain coefficient and solar reflectance, derived from spectral selectivity of materials and variation of solar spectrum, through spectral sensitivity analysis using multitudes of spectral data of available commercially architectural materials and several calculated typical solar spectrums. To reflect spectral characteristics on the actual calculation, this paper purposes the use of two waveband value: ultraviolet-visible $(\mathrm{UV}+\mathrm{V})$ and near-infrared (NIR).
\end{abstract}

Keywords: Glass, Architectural material, Solar heat gain coefficient, Solar reflectance, Spectral characteristics, Ultraviolet-visible region, Near-infrared region

ガラス，建材，日射熟取得率，日射反射率，分光特性，紫外可視光域，近赤外域

1 はじめに

近年, アトリウムのような特殊な建築に限らず, 一般的なオ フィスビルや住宅などの建築においても，眺望の確保や昼光利 用といった観点から開口面積は増大する傾向であり, 透過日射 が居住環境へ及ぼす影響や日射熱侵入による熱負荷への影響を， より詳細かつ正確に予測する必要がある．日射の分光分布は太 陽高度や大気の状態, 直達および拡散日射によって異なるもの であるが, 従来は計算の煩雑さや物性值変化への影響の小ささ から ${ }^{1)}$ 基準太陽光の分光分布を想定した日射物性值 ${ }^{2)}$ が一般 的に用いられてきた。しかしながら，近年広く普及するように なった波長選択性の高いガラスに扔いては, この単一の指標が 日射熱取得算出の誤差要因となることが指摘されている ${ }^{3)}$. ま た, 波長特性が人体の温熱感に与える影響 ${ }^{4)}$ などを考慮した瀻 細な環境計画を考える上では，指標として不足している。

一方, 屋外都市空間に目を向けると, 空間を構成する外皮は, 例えば建築室内への熱負荷低減を目的とした低放射ガラスや, 固 有の光学的性質を有する金属パネルなど多様な人工建材で構成 されており，これら外皮を介して屋外居住域へ伝達する反射日 射は，近赤外域の成分を多く含むなど天空下とは異なる波長特 性となっていることが考えられる。また，都市を大きなスケー ルで捉えると, 近年重要視されるようになったヒートアイラン ド対策の一環として波長選択性が高い遮熱塗料が用いられるこ とがあり，このような表面の反射日射量の算定において日射の 分光分布の変化と併せて誤差要因となり得る.

従来の基準太陽光に対する単一の指標に起因する誤差を明ら かにするため, 筆者らはガラスメーカー提供による分光透過およ び反射率のデータ, 収集した市販建材サンプルを分光放射計で測
定した分光反射率のデータをもとに, 夏季および冬季を代表する 日射の分光分布に対するガラスの日射熱取得率および建材全般の 日射反射率の感度特性を分析した。ここで，実用的な計算におい て詳細な波長毎の計算を行うことはあまり現実的ではないこと から, 780nm を境界とする紫外可視光域:UV+V(ultravioletvisible) および近赤外域:NIR(near-infrared) の 2 波長带 注 1) によって, ガラスの日射熱取得率および建材表面の日射反射率を 評価する方法を提案し, 2 波長帯による指標の精度を検討した。 なお，本論文は文献 5)6）を加筆修正してまとめたものである.

\section{2 日射の分光特性}

\subsection{Bird の分光日射モデル}

地表面近傍における日射の分光分布を与えるモデル式は 数多くあるが, Bird のモデル 7) は比較的容易な計算で 晴天時の多様な大気状態下での, 波長 $\lambda に$ に扔る法線面 直達日射量 $I_{D N}(\lambda)\left[\mathrm{W} /\left(\mathrm{m}^{2} \cdot \mathrm{nm}\right)\right]$ および水平面拡散日射量 $I_{S H}(\lambda)\left[\mathrm{W} /\left(\mathrm{m}^{2} \cdot \mathrm{nm}\right)\right]$ の分光分布を得ることができる，このモ デルは簡易な数式と数表で構成されており，300-4000 $\mathrm{nm}$ の波 長域を扱っている.

実際には，122 の波長に対する大気圈外日射量および大気の 吸収係数の数表を入力条件として計算している. 大気の状態を 表す主要なパラメータは, 太陽高度 $\mathrm{h}\left[^{\circ}\right]$, 波長 $500 \mathrm{~nm}$ におけ る大気の混濁度指数 $\tau_{05}[-]$, オゾン厚さ $\mathrm{O} 3[\mathrm{~atm} \mathrm{~cm}]$, 可降水 量 W $[\mathrm{cm}]$ である. 大気の状態に応じて, レイリー散乱, エアロ ゾル減衰, オゾン吸収, 水蒸気吸収および混合ガス吸収の透過 率を算出する過程が，このモデルの中心となっている．詳細に ついては文献 7)を参照されたい。
* 東京都立大学大学院工学研究科 博士課程. 工修

** 東京都立大学大学院工学研究科 教授. 工博

*** 東京都立大学大学院工学研究科 助教授・博士 (工学)
Graduate Student, Graduate School of Eng., Tokyo Metropolitan Univ., M. Eng. Prof., Graduate School of Eng., Tokyo Metropolitan Univ., Dr. Eng. Assoc. Prof., Graduate School of Eng., Tokyo Metropolitan Univ., Dr. Eng. 


\section{2 パラメータの設定}

前項で述べたモデルが示唆するように，大気の状態によって 時々刻々と日射の分光分布は変化する. 日射の分光分布に大き く影響を与える要素を列挙すると以下のようになる。

・太陽高度はレイリー散乱に大きく影響し、太陽高度が高い 場合は分光日射量のピークが短い波長にあり，太陽高度が 低い場合は長い波長に推移する。

- 大気混濁度が大きくなると, 直達日射の可視光域が減衰し, 拡散日射の近赤外域が増加する。

- 可降水量が増大寸ると, 水蒸気吸収帯の減衰が大きくなる.

表 1 分光日射の計算条件 (北緯 $\mathbf{3 5 . 7 ^ { \circ }}$, 東経 $139.8^{\circ}$ )

\begin{tabular}{|c|c|c|c|c|c|}
\hline & 月日 & 時間 & $h\left[^{\circ}\right]$ & $\tau_{05}[-]$ & $W[\mathrm{~cm}]$ \\
\hline \multirow{2}{*}{ 夏 } & \multirow{2}{*}{$7 / 21$} & $12: 00$ & 74.5 & 0.3 & 2.9 \\
\cline { 3 - 4 } & & $17: 00$ & 21.0 & & \\
\hline \multirow{2}{*}{ 冬 } & \multirow{2}{*}{$1 / 21$} & $12: 00$ & 34.2 & 0.1 & 0.9 \\
\cline { 3 - 4 } & & $16: 00$ & 9.0 & & \\
\hline
\end{tabular}

本論文ではこれらの変動要因を反映させつつ，真夏と真冬に おける代表的な分光日射を再現するため，表 1 に示すようにパ ラメータを設定した. $\mathrm{O} 3$ は 0.34 , 地表面アルベド $\rho_{\mathrm{G}}$ は 0.2 , エアロゾルの粒径分布に関する係数 $\alpha$ は 1.14 とした. プログラ ムは NREL : National Renewable Energy Laboratory にて 公開されている SPCTRAL2 を若干変更したものを使用した。

\section{3 日射物性値算出に用いた日射の分光分布}

図 1 に, 上記の条件で算出した法線面直達及び水平面拡散日射 量の分光分布を示す. それぞれ基準太陽光 $\left(\tau_{05}=0.27, \mathrm{O} 3=0.34\right.$, $\mathrm{W}=1.42$ ，エアマス 1.5 , 傾斜角 $37^{\circ}$ に扔ける傾斜面日射量) の 分光分布を併せて示す. 凡例に示す各日射の名前は夏/冬, 数 值は太陽高度, 法線面直達/水平面拡散をそれぞれ表す。凡例 の横に全波長域 (300-4000nm) の積分日射量を併記する．図中 の縦線は可視光域の終端 $(780 \mathrm{~nm})$ を示している.太陽高度が高 いときの直達日射は基準太陽光と比較的近い分光分布であるが， 太陽高度が低いときは分光日射量のピーク位置が大きく異なっ てくる．拡散日射では基準太陽光と比較して，ピークから近赤 外域にかけての低下が急である.

また，図 2 は，これらの分光日射の全波長域積分値に対する 各波長までの積分値の割合を示したものである．凡例横の值は， 紫外可視光域 UV+V と近赤外域 NIR の日射量比率である. 基 準太陽光では可視光域終端までの割合が $56 \%$ ある。.太陽高度 の低い直達日射では $37 \%$ と小さくるのに対して, 夏の日中の 拡散日射では $79 \%$ まて達しており，エネルギーの分布が大きく 異なっていることがわかる.

\section{3 板ガラスの日射物性値の分光感度特性}

\section{1 ガラスのデータサンプル}

検討に用いたガラスの分光透過率および反射率データは，ガ ラスメーカー提供によるものである注 2)。ガラスの種類は，透 明 (単層 3 , 複層 2 ), 熱線吸収 (単層 4 , 複層 3 ), 熱線反射 (単層 5 , 複層 5 ), 高遮蔽性能熱線反射 (単層 6 , 複層 6 ), 低放射ガラス (複層 4) の 5 種類 (合計 38) であり, 各ガラスとも 5-6 mm 厚 のデータを選定した．波長域は 300-2100nm までとなっている.

図 3 に, 5 種類の代表的なガラスの分光透過率を示す. 透明ガ

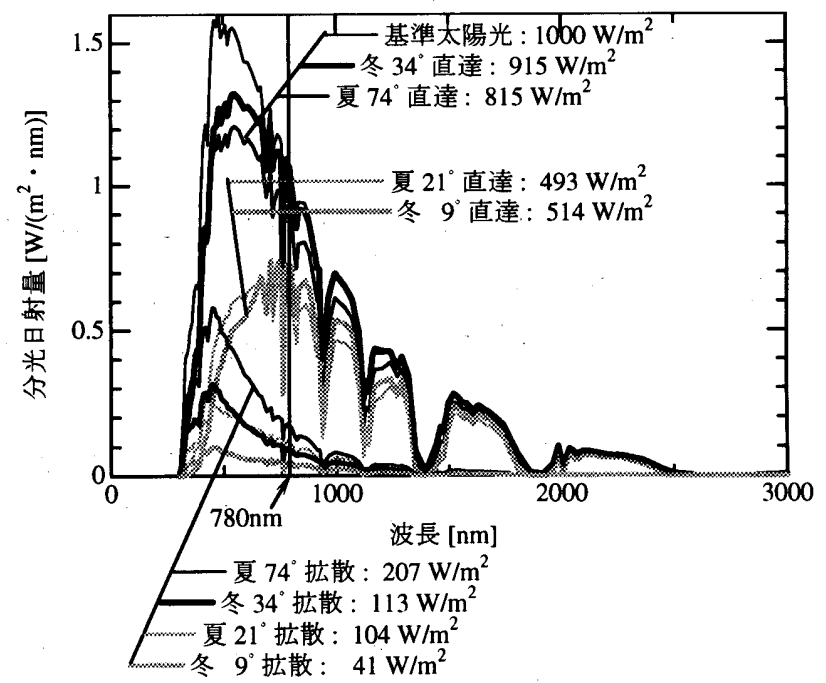

図 1 Bird モデルによる日射の分光分布

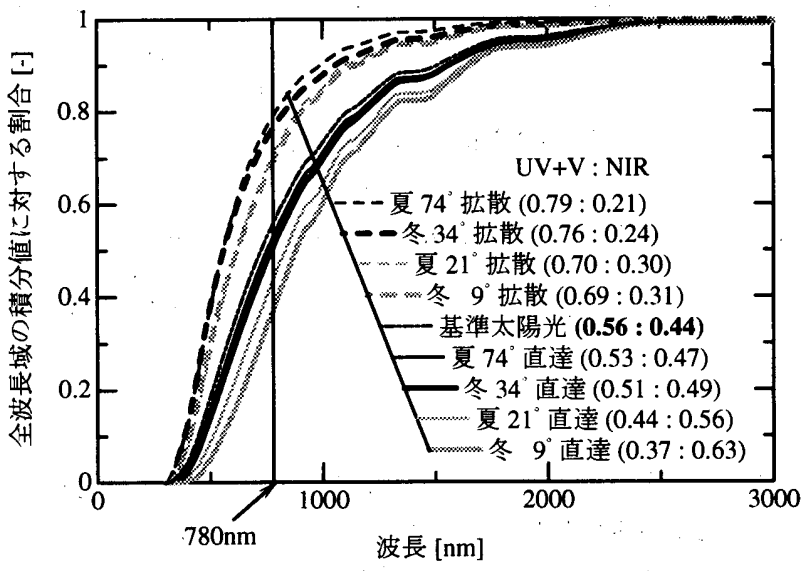

図 2 全波長域積分值に対する各波長までの積分值の割合

ラスは高い透過率で, 高遮蔽性能熱線反射ガラスは低い透過率 で比較的フラットな分光特性である．その他のガラスは $600 \mathrm{~nm}$ 付近でのピークから近赤外域にかけての減衰が大きく，特に低 放射ガラスは紫外可視光域と近赤外域での透過率の差が大きい. このような波長選択性はガラスの原料に添加する金属類やガラ ス表面に施す金属膜によって生じるものであり，使用する金属 の種類や量によって変化してくるが, 本論文で扱ったガラスに 関しては, ガラス種類ごとに上記のような傾向が見られた.

\section{2 代表的なガラスにおける透過率の分光感度特性}

一般的な熱負荷計算では，本来傾斜面日射量である基準太陽 光の分光分布を平行光線の法線入射と想定して JIS R $3106^{2)}$ に示されている方法で日射透過率や日射熱取得率を算出してお き, 直達日射に对しては時々刻々と変化する入射角に応じた入 射角特性の係数を, 拡散日射に対しては半球積分の係数を乗じ て, 透過日射量や侵入日射量の算出を行う.ここで, 本論文では 建材の分光特性に起因する, 日射の分光分布の変化によって生 じる波長積分値の偏差のみを検討するために, SPCTRAL2に より算出した代表的な 4 つの日時における直達日射及び拡散日 射が有する分光分布による平行光線の法線入射を想定して, 式 （1）で 300-2100nm の波長積分値を算出し，基準太陽光を用い た既往の算出方法と同列に扱った。ただし，入射角による日射 透過反射率の変化は大きく，特にガラスの屈折率または吸収係 数の波長分散が大きい場合やガラスが空気以外の水など波長選 


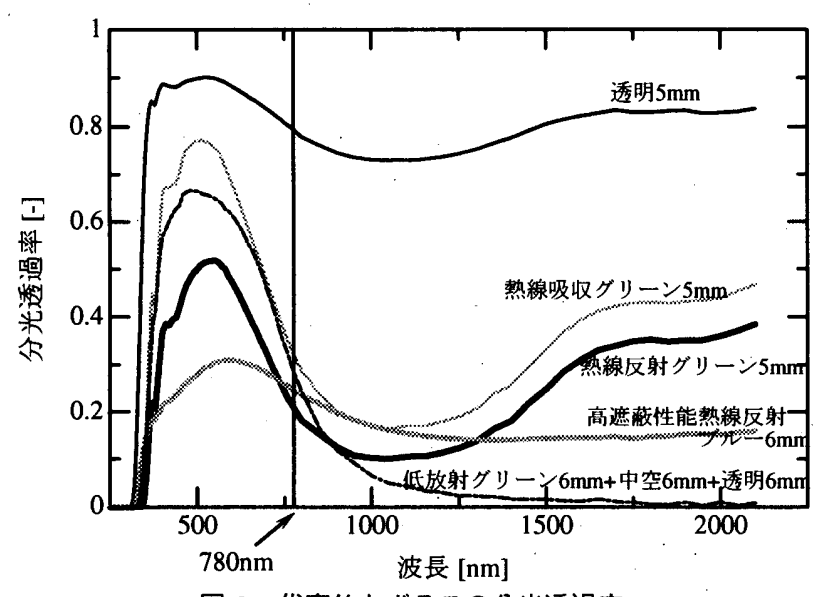

図 3 代表的なガラスの分光透過率

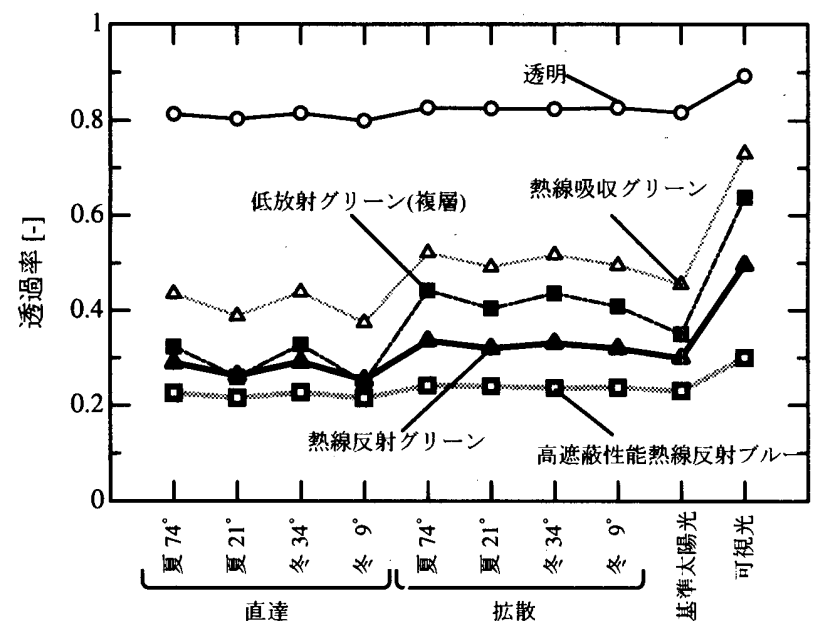

図 4 日射の分光分布による代表的なガラス透過率の变化

択性のある媒体にガラスが接している場合などは，入射角特性 も日射の分光分布ごとに変化が生じるが，本論文ではそこまで 立ち入らずに，特定の方位の鉛直面を想定しない法線入射によ る感度解析と位置付けている。

$$
\tau=\int \tau(\lambda) I(\lambda) d \lambda / \int I(\lambda) d \lambda
$$

ここで,

$\tau$ : 或る分光分布の入射日射に対する透過率 [-] $\tau(\lambda):$ 波長 $\lambda$ における分光透過率 $[-]$

$I(\lambda)$ : 波長 $\lambda$ における入射日射の日射量 $\left[\mathrm{W} /\left(\mathrm{m}^{2} \cdot \mathrm{nm}\right)\right]$

図 4 に，上記 5 つのガラスにおける複数の日射の分光分布に 対する日射透過率の変化を, 可視光透過率と併せて示す. 全般 的には, 基準太陽光の場合と比較して, 直達日射に対しては小 さく，掋散日射に対しては大きい値となっている，また，太陽 高度が高い時の方が透過率は大きい值となっている，特に，波 長選択性の高い熱線吸収, 熱線, 反射および低放射ガラスにおい ては有意な差が見られる。

直達日射は拡散日射と比較して長波長側に日射量が分布して いることと, 太陽高度が高い時の日射に対して低い場合の方が 同様に長波長側に分布があることにより，可視光域に対して近 赤外域での透過率が小さくなるガラスの波長選択性と併せてこ のような結果になったことが説明できる.

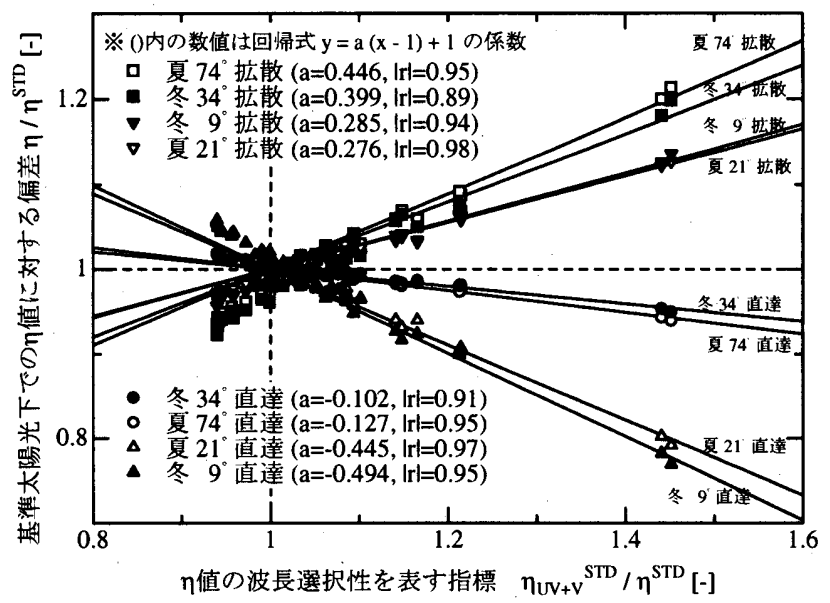

(a) ガラスの波長選択性との相関

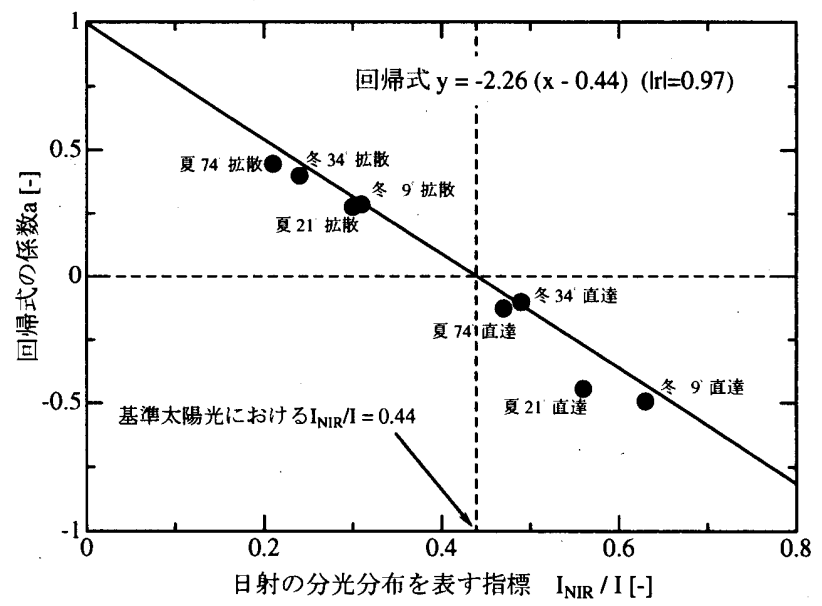

(b) 日射の状態との相関

図 5 ガラスの波長選択性・日射の状態と $\eta$ 值の偏差との相関性

\subsection{2 波長帯による波長選択性の評価}

前項の結果は, 波長選択性の高いガラスにおいて, 日射の分 光分布の変動が日射熱取得の計算に誤差を生じさせることを示 唆しているが, 建築の実用的な熱計算において数多くの波長毎 に日射の計算を行うのは煩雑である. そこで, 本論文では式 (1) での積分波長域を紫外可視光域:UV+V $(300-780 \mathrm{~nm})$ および近 赤外域:NIR(780-2100nm)の 2 つに分割した指標による評価方 法を提案する。 なお, 反射率および吸収率 (分光透過率および反 射率から算出) の積分も式 (1) と同様に行った.

2 波長帯の物性值は例えば透過率であれば紫外可視光域につい ては $\tau_{\mathrm{UV}+\mathrm{V}}$ ，近赤外域については $\tau_{\mathrm{NIR}}$ のように表記する。こ れらの值は，各波長帯の日射量 ${ }^{\text {注 } 3)} \mathrm{I}_{\mathrm{UV}}+\mathrm{V}$ および $\mathrm{I}_{\mathrm{NIR}}\left[\mathrm{W} / \mathrm{m}^{2}\right]$ が乗じる対象であり，数式で表すと式 (2) となる。 また，基準 太陽光の分光分布に対する物性值にはサフィックス STD を付記 する。

$$
\tau=I_{U V+V} / I \cdot \tau_{U V+V}+I_{N I R} / I \cdot \tau_{N I R}
$$

\section{4 日射熱取得率の分光感度特性}

日射熱取得率 (以下 $\eta$ 值) の算出にあたっては，熱伝達率およ び温度条件については JIS R $3106^{2)}$ に記述されている夏季鉛 直面を想定した方法を用いた。 日射の透過・反射・吸収率につ いては，3.2節で述べたように直達および拡散日射について平行 光線の法線入射を想定した波長積分を行っている. 
表 2 代表的なガラスの基準太陽光に対する波長帯別の物性值 (“ALL”は全波長帯 300-2100nm での積分值、“可視光”は可視光透過・反射率)

\begin{tabular}{|c|c|c|c|c|c|c|c|c|c|c|c|c|}
\hline & & \multicolumn{4}{|c|}{ 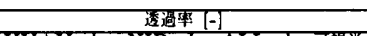 } & \multicolumn{4}{|c|}{ 反射事 $[-1$} & \multirow{2}{*}{\multicolumn{3}{|c|}{$\eta$ 值 }} \\
\hline \multirow{3}{*}{ 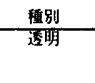 } & 色·㫲兰 & UV+V & & ALL & 可䅐 & OVt & & ALI & & & & \\
\hline & $3 \mathrm{~mm}$ & 0.878 & 0.829 & 0.858 & 0.902 & 0.081 & 0.076 & 0.079 & 0.082 & 0.892 & 0.862 & 0.880 \\
\hline & $\frac{5 \mathrm{~mm}}{6 \mathrm{~mm}}$ & 0.855 & $\begin{array}{l}0.761 \\
0.732\end{array}$ & 0.817 & 0.893 & $\frac{0.076}{0.078}$ & 0.069 & $\begin{array}{l}0.073 \\
0.073\end{array}$ & $\frac{0.078}{0.080}$ & 0.878 & 0.819 & 0.855 \\
\hline \multirow[t]{4}{*}{ 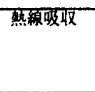 } & $\frac{6 \mathrm{~mm}}{7 \mu-5 \mathrm{~mm}}$ & $\begin{array}{l}0.841 \\
0.704 \\
\end{array}$ & $\frac{0.32}{0.442}$ & $\frac{0.997}{0.598}$ & $\begin{array}{l}0.880 \\
0.779 \\
\end{array}$ & 0.0 .08 & $\frac{0.000}{0.052}$ & $\begin{array}{l}0.013 \\
0.062 \\
\end{array}$ & 0.000 & 0.800 & 0.001 & \\
\hline & qL $=5 \mathrm{~mm}$ & 0.506 & 0.499 & 0.503 & 0.492 & 0.055 & 0.056 & 0.056 & 0.054 & 0.656 & 0.651 & 0.654 \\
\hline & 7ロンス $5 \mathrm{~mm}$ & 0.552 & 0.578 & 0.562 & 0.558 & 0.057 & 0.060 & 0.058 & 0.057 & 0.686 & 0.702 & 0.692 \\
\hline & $\frac{17-25 \mathrm{~mm}}{3176 \mathrm{~mm}}$ & $\frac{0.597}{0.602}$ & $\begin{array}{l}0.242 \\
0.653\end{array}$ & $\frac{0.454}{0.622 .}$ & $\frac{0.732}{0.630}$ & 0.062 & 0.047 & $\begin{array}{l}0.056 \\
0.227\end{array}$ & $\frac{0.068}{0.323}$ & $\frac{0.714}{0.636}$ & $\frac{0.485}{0.729}$ & $\frac{0.622}{0.674}$ \\
\hline \multirow{3}{*}{ 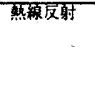 } & $7 n-6 \mathrm{~mm}$ & 0.474 & 0.329 & 0.416 & 0.538 & 0.218 & 0.066 & 0.157 & 0.252 & $\frac{.0580}{0.580}$ & 0.537 & 0.562 \\
\hline & $3 l-6 \mathrm{~mm}$ & 0.317 & 0.385 & 0.344 & 0.301 & 0.112 & 0.072 & 0.096 & 0.107 & 0.513 & 0.571 & 0.536 \\
\hline & 70726m & 0.355 & $\begin{array}{l}0.460 \\
0.165\end{array}$ & 0.397 & 0.352 & $\frac{0.126}{0.189}$ & 0.083 & 0.109 & 0.130 & $\frac{0.533}{0.11}$ & 0.617 & 0.567 \\
\hline \multirow{5}{*}{ 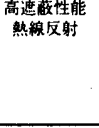 } & 涪 & $\frac{0.389}{0.081}$ & $\frac{0.165}{0.060}$ & $\frac{0.299}{0.072}$ & $\begin{array}{l}0.496 \\
0.092 \\
\end{array}$ & $\frac{0.168}{0.389}$ & $\begin{array}{l}0.048 \\
0.298\end{array}$ & $\frac{0.120}{0.352}$ & $\frac{0.219}{0.419}$ & $\frac{0.541}{0.227}$ & $\frac{0.435}{0.236}$ & $\frac{0.498}{0.231}$ \\
\hline & 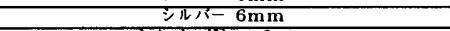 & 0.189 & 0.141 & 0.170 & 0.204 & 0.221 & 0.180 & & & & 0.336 & \\
\hline & $\sum \pi /-3 l-6 \mathrm{~mm}$ & 0. & & & & & & & & & 0.462 & 0.486 \\
\hline & $\frac{n-6 \mathrm{~mm}}{1-7 n-6 \mathrm{mn}}$ & & 0.171 & 0.229 & 0.300 & $\frac{0.151}{0.184}$ & 0.158 & 0.154 & 0.150 & 0.440 & 0.370 & 0.412 \\
\hline & $=2,5-51+7 h-6 \mathrm{~mm}$ & 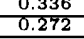 & $\frac{0.233}{0.172}$ & $\frac{0.294}{0.231}$ & $\frac{0.3}{0.3}$ & $\frac{0.184}{0.286}$ & $\frac{0.128}{0.168}$ & $\begin{array}{l}0.161 \\
0.238\end{array}$ & 0.1922 & $\frac{0.484}{0.400}$ & $\frac{0.430}{0.364}$ & $\frac{0.462}{0.386}$ \\
\hline & $3 \mathrm{~mm}+$ 茕気 $6 \mathrm{~mm}+$ 透明 $3 \mathrm{n}$ & $\overline{0.781}$ & $\overline{0.692}$ & 0.745 & 0.820 & $\overline{0.144}$ & $\overline{0.128}$ & $\overline{0.138}$ & 0.150 & 0.811 & 0.762 & 0.790 \\
\hline 梱) & $\frac{1+x^{2}}{18}$ & 0.743 & & & & & & & 0.141 & & & 0.753 \\
\hline \multirow{3}{*}{ 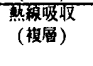 } & 7ル-5mm+空 & 0.615 & 0.340 & 0.505 & & 0.108 & $\overline{0.0}$ & & & & & 0.606 \\
\hline & $5 \mathrm{~mm}+x^{2}$ & & 0.384 & 0. & & & & & & & 0.528 & 0.539 \\
\hline & 70 & & 0.444 & & & & & & & & & \\
\hline \multirow{4}{*}{ 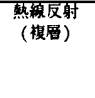 } & & & & 0.513 & & & & & & & & \\
\hline & & & $\frac{0.2}{0.2}$ & & & & & & & & & \\
\hline & & & & & & & & & & & & \\
\hline & & & & & & & & & & & & 54 \\
\hline \multirow{5}{*}{ 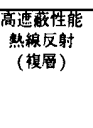 } & 新 & & 0.1 & & & & & & & & & 168 \\
\hline & $\sum n$ & & & & & & & & & & & 100 \\
\hline & हार & & & & & & & & 0.1 & & & 0.384 \\
\hline & $6 \mathrm{~m}$ & & 0. & & & & & & & & & 0.323 \\
\hline & $T_{0}$ & & & & & & & & & & & 69 \\
\hline \multirow{4}{*}{ 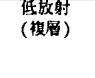 } & $\frac{2 \pi-1}{3}$ & & & & & & & & & & & $\frac{0.307}{0.424}$ \\
\hline & シルハー $-6 \mathrm{~m}$ & & 0. & 0 & 0 & o. & 7 & 0 & 0. & & 0.394 & 0.556 \\
\hline & $=.2-19 \pi y$ & 0.563 & 084 & 0.370 & 0.676 & $\frac{5.118}{1.120}$ & 0.447 & 150 & & 638 & 0.179 & $\frac{.443}{507}$ \\
\hline & 3ग & & & 0.518 & & & 0.263 & 0.178 & 0.122 & & & .597 \\
\hline
\end{tabular}

図 5 は全 38 のガラスを対象に 8 種類の入射日射で算出した $\eta$ 值についてガラスの波長選択性と日射の分光分布の関係を分 析したものである。図 5(a) ではガラスの波長選択性と $\eta$ 值の 偏差の関係性を検討した，横軸にガラスの波長選択性の指標と して基準太陽光での紫外可視光域: $\mathrm{UV}+\mathrm{V}$ 積分值と全波長域積 分値の比 $\eta_{\mathrm{UV}+\mathrm{V}}{ }^{\mathrm{STD}} / \eta^{\mathrm{STD}}$ を, 縦軸に $\eta$ 値の偏差として各入 射日射と基準太陽光での $\eta$ 值の比 $\eta / \eta^{\mathrm{STD}}$ をとった. 横軸の数 值が大きいほど，可視光域の日射をよく透過して近赤外域の日 射を遮蔽する, 室内側にとっては性能の高いガラスの指標とい える 注 4). 図中で低放射ガラスは $\eta_{\mathrm{UV}+\mathrm{V}}{ }^{\mathrm{STD}} / \eta^{\mathrm{STD}}$ が約 1.4 で他のガラスより高い值であり, $\eta / \eta^{\mathrm{STD}}$ は最小 0.8 から最大 1.2 となり, 単一の指標 $\eta^{S T D}$ を用いた場合は日射の分光分布に よって, 約 $\pm 20 \%$ の日射熱取得率の偏差が生じているというこ とになる，その他のガラスは $10 \%$ 以内の偏差である。また，凡 例横に回帰式 $\mathrm{y}=\mathrm{a}(\mathrm{x}-1)+1$ の係数 $\mathrm{a}$ および相関係数を示し ているが, 日射の条件（直達・拡散, 太陽高度）ごとに波長選 択性と $\eta$ の偏差に高い相関性があることがわかる。

また，図 5(b) に示すように横軸に日射の分光分布を表す指 標として近赤外域の日射量の全波長域に対する比率 $\mathrm{I}_{\mathrm{NIR}} / \mathrm{I}$ を, 縦軸に図 5(a) における各日射の分光分布に対する回帰式の係数 $\mathrm{a}$ をとたところ, 高い相関性で回帰式を得た。

ここで, 紫外可梘光および近赤外域での波長分散が全く無 い場合は基準太陽光下の $\eta^{\mathrm{STD}}$ を用いて任意の分光日射下 の $\eta$ は式 (3) で表せることから, ガラスの波長選択性を表す

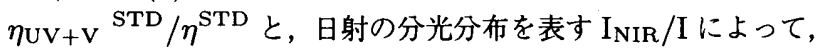
全波長域について波長積分した精算の $\eta$ 値に対する補正係数 は式 (4) で表される. 式中の係数は基準太陽光における波長帯 日射量の割合を表しており, 0.44 は $\mathrm{I}_{\mathrm{NIR}} \mathrm{STD} / \mathrm{I}^{\mathrm{STD}}, 2.27$ は $\mathrm{I}^{\mathrm{STD}} / \mathrm{I}_{\mathrm{NIR}}$ STD の值である。この式 (4)に対して図 5(b)にお ける回䚻式による係数は殆ど同じであることから, 表 2 に一覧 を示したガラスについては，2 波長帯による評価によって精度 良く詳細な分光特性を反映することができるといえる。ただし，
本論文で扱わなかった，各波長帯での波長分散が大きいガラス では，誤差が大きくなることが考えられる。

$$
\begin{gathered}
\eta=I_{U V+V} / I \cdot \eta_{U V+V} S T D+I_{N I R} / I \cdot \eta_{N I R} S T D \\
\eta / \eta^{S T D}=-2.27\left(\eta_{U V+V} S T D / \eta^{S T D}-1\right)\left(I_{N I R} / I-0.44\right)+1
\end{gathered}
$$

\section{4 建材全般の日射反射率の分光感度特性}

\section{1 測定対象の建材}

表 3 に測定対象とした建材サンプル 100 個の一覧を示す.こ れらの大半は建材メーカー提供によるものであり, 一般に市販 されているものである.これらの分類および種類はメーカーが 表示している用途等に基づいたものである. 塗料系に分類した 遮熱塗料については,『断熱塗料』と称しているもの等も含めた。 各同一種類の建材は,グレー・白を中心に色を揃えた。

\begin{tabular}{|c|c|c|}
\hline 分類 & 種類 & 数量 \\
\hline \multirow[t]{3}{*}{ タイル系 } & 外壁用タイル & 3 \\
\hline & 舗装用タイル & 3 \\
\hline & レンガ & 1 \\
\hline \multirow[t]{3}{*}{ 金属板 } & アルミサッシ & 4 \\
\hline & 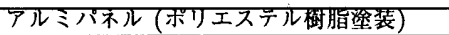 & 6 \\
\hline & ステンレスパネル (樹脂乲装) & 15 \\
\hline \multirow[t]{3}{*}{ 石材 } & 大理石 (天然・大造) & 7 \\
\hline & 御影石 & 16 \\
\hline & 砂署・スレート & 6 \\
\hline \multirow[t]{2}{*}{ 染装系 } & 一般塗料 (アクリル・ウレタンゴム) & 5 \\
\hline & 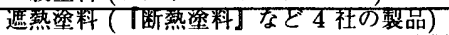 & 16 \\
\hline コンクリート & コンクリート製品（コンクリート, ALC) & 2 \\
\hline \multirow[t]{4}{*}{ その他 } & 伝㓍材料 (㵞喰・珪澡土など) & 5 \\
\hline & 舖装材 (樹脂系・骨材系) & 5 \\
\hline & 化粧板 (理䤃カルシウム板) & 6 \\
\hline & 翆 & 100 \\
\hline
\end{tabular}

表 3 測定対象の建材サンプルー筧

\section{2 測定装置の概要}

図 6 に分光反射率計測に用いた分光放射計 (Analytical Spectral Devices, Inc. 製 “Field Spec Pro Full Range JR.") のシ 


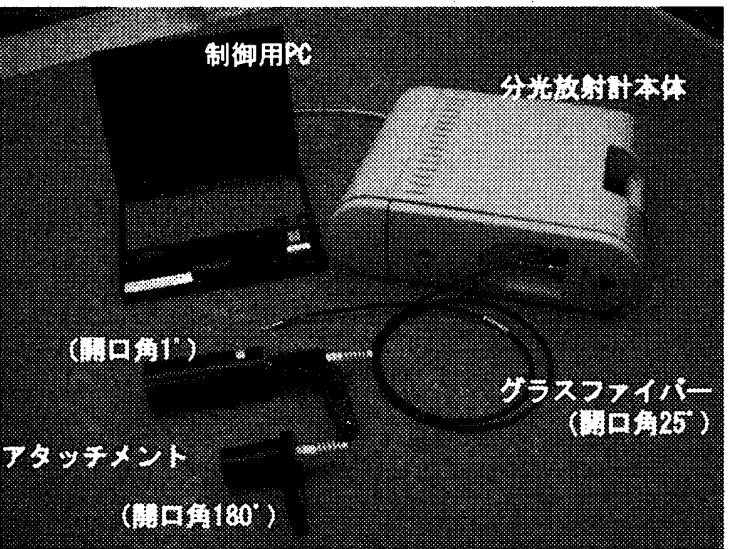

図 6 測定に用いた分光放射計

ステムを示す．開口角 $25^{\circ}$ のグラスファイバーを有する本体と， 計測制御およびデー夕保存を行う PC, 開口角を変更するアタッチ メント $\left(1^{\circ}, 180^{\circ}\right)$ からなる. センサは可視光域 $(350-1000 \mathrm{~nm})$, 近赤外 1(1000-1800nm), 近赤外 2(1800-2500nm) の 3 つが 内蔵されており，350-2500nm まで $1 \mathrm{~nm}$ 間隔で分光放射輝度 $\left[\mathrm{W} /\left(\mathrm{m}^{2} \cdot \mathrm{sr} \cdot \mathrm{nm}\right)\right]$ を得る. 白色標準試料として Spectralon ${ }^{(\mathrm{TM})}$ を用いて，入射角 $45^{\circ}$ における半球分光反射率 $\rho(\lambda)[-]$ を計測 した注 5) 注 6)。

\section{3 分光反射率の特性}

図 7 に半球分光反射率の測定結果の一部を建材の種類別に示 す. 全般的に紫外可視光域よりも近赤外域での反射率が高い傾 向にあるが，a）に示すタイル系のレンガは原料である土の分光 特性に由来して，そのような傾向になると考えられる，b)に示 す金属板も近赤外域が高くなる傾向にあるが，材料そのものと いうよりは表面の処理方法や表面皮膜の素材に大きく左右され るようであった．最も波長選択性が大きく見られたのはd）に 示す塗料系の遮熱塗料であり, ウレタンゴム塗装 (グレー) と遮 熱塗料 (グレー) は同じ色で可視光域でのフラットな特性も類似 していながら, 近赤外域以降での分光分布は全く異なっている. 遮熱塗料は製品による固体差がかなり大きく，表面に微小な凹 凸を設けて近赤外域の波長特性を変化させる等の特徽があった. これらの近赤外域の反射率が高くなる材料に対しては, 色など による反射率の推定が難しいといえる，それに対して，c)に示 す石材や e) に示すコンクリートは比較的フラットな分光特性で ある。 また，石材やコンクリートと同様にf）に示したその他の 漆喰においても $1400 \mathrm{~nm}$ および $1900 \mathrm{~nm}$ 付近における水蒸気の 吸収による反射率の低下が大きく見られ，含水率によってこの 低下の程度が变化する。しかしながら, 波長積分值への影響は 小さいものと思われる。

\section{4 分光感度特性と相関性の分析}

ガラスと同様に紫外可視光域 UV $+\mathrm{V}(350-780 \mathrm{~nm})$ および近 赤外域 NIR(780-2500nm) の波長帯で分割して日射反射率を評 価する，なお，反射率の波長積分は 3.2 節で示したガラスの透 過率算出と同様に, 拡散・直達日射を平行光線の法線入射と想 定して式 (5) で行った。

$$
\rho=\int \rho(\lambda) I(\lambda) d \lambda / \int I(\lambda) d \lambda
$$

図 8(a) は，横軸に反射率の波長選択性を表す指標として基 準太陽光下での近赤外域反射率の全波長域の反射率に対する比 $\rho_{\mathrm{NIR}}{ }^{\mathrm{STD}} / \rho^{\mathrm{STD}}$ をとり, 縦軸に任意の入射日射による反射率の

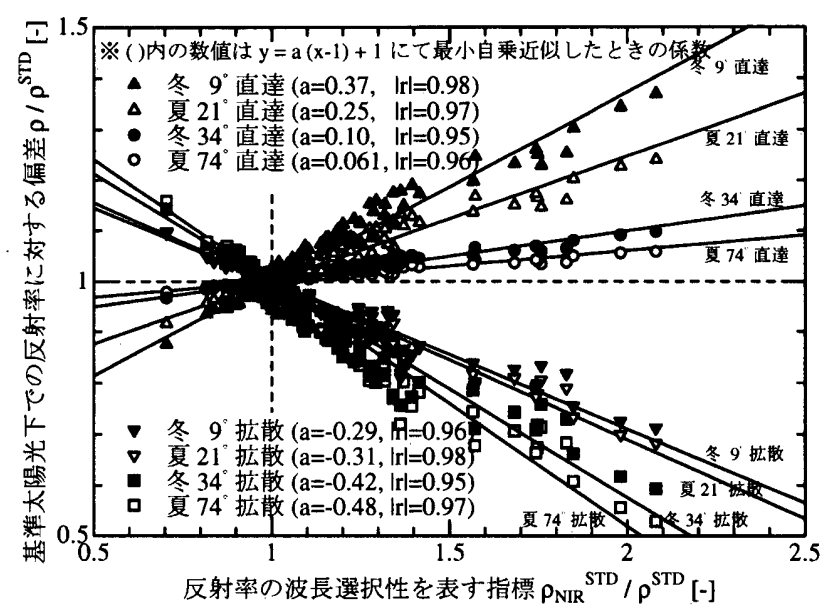

(a) 材料の波長選択性と反射率の変動の相関

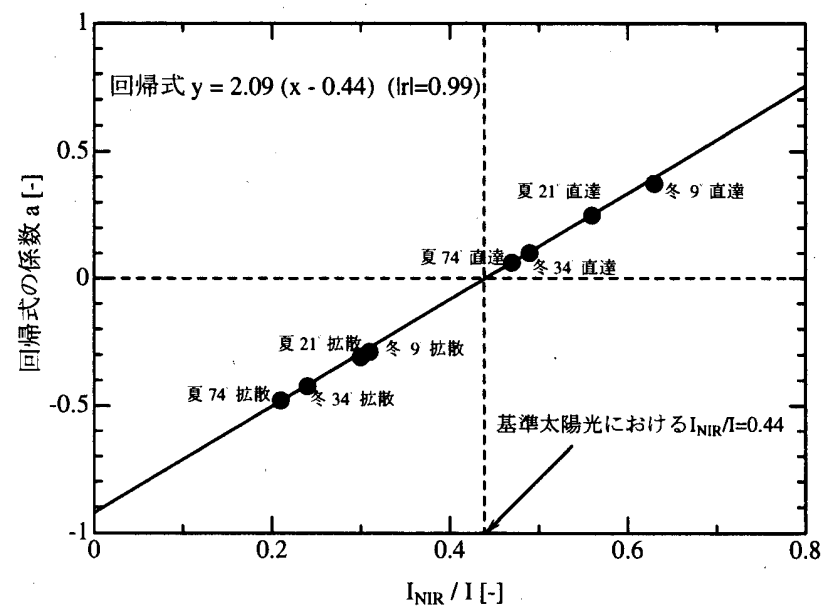

(b) 日射の状態と反射率変動の相関

図 8 建材の波長選択性・日射の状態と日射反射率の偏差との相関性

基準太陽光下での反射率に対する比 $\rho / \rho^{\mathrm{STD}}$ をとったものであ る.これらは表 3 に示した 100 種類の建材を対象にした結果で ある. 図中で横軸 1.7 以上を示しているプロットは図 7 におい て高い波長選択性を有していた遮熱塗料であり，日射の分光分布 の変化によって基準太陽光での反射率に対して最大で $\pm 40 \%$ 程 度の偏差が生じることがわかる．また，ガラスの $\eta$ 值と同様に， 日射の分光分布ごとに波長選択性と反射率の変動との間に強い 相関性が見られ，各日射ごとに回帰式を作成した。

また，図 8(b) に示すように，横軸に近赤外域日射量 $\mathrm{I}_{\mathrm{NIR}}$ の 全波長域の日射量 I に対する比率 $\mathrm{I}_{\mathrm{NIR}} / \mathrm{I}$ と, 縦軸に図 $8(\mathrm{a})$ に おける回帰式の傾き $\mathrm{a}$ をったところ, 高い相関性で回帰式を 得た.

ここで，紫外可視光域および近赤外域における反射率の波長 分散が全く無い場合は，基準太陽光下の $\rho^{\mathrm{STD}}$ を用いて任意の分 光日射下の $\rho$ は式 (6) で表せることから, 建材の波長選択性を 表す $\rho_{\mathrm{NIR}} \mathrm{STD} / \rho^{\mathrm{STD}}$ と, 日射の分光分布を表す $\mathrm{I}_{\mathrm{NIR}} / \mathrm{I}$ によっ て，全波長域について波長積分した精算の反射率に対する補正 係数は式 (7) で表される. 式中の係数は基準太陽光における波 長帯日射量の割合を表しており，0.44は $\mathrm{I}_{\mathrm{NIR}} \mathrm{STD} / \mathrm{I}^{\mathrm{STD}}, 1.79$ は $\mathrm{I}^{\mathrm{STD}} / \mathrm{I}_{\mathrm{UV}+\mathrm{V}} \mathrm{STD}$ の值である。この式 (7) に対して図 8(b) による回帰式の係数は, ガラスの場合ほど近い值とはならない が, 図 7 や表 4 に一部を示した建材についても，概ね 2 波長帯 


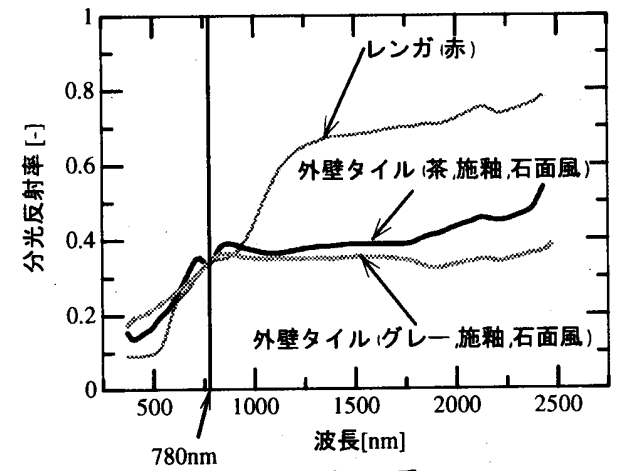

(a) タイル系

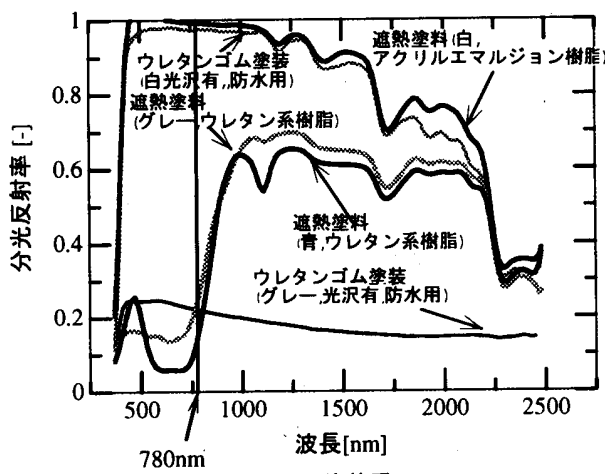

(d) 粱装系

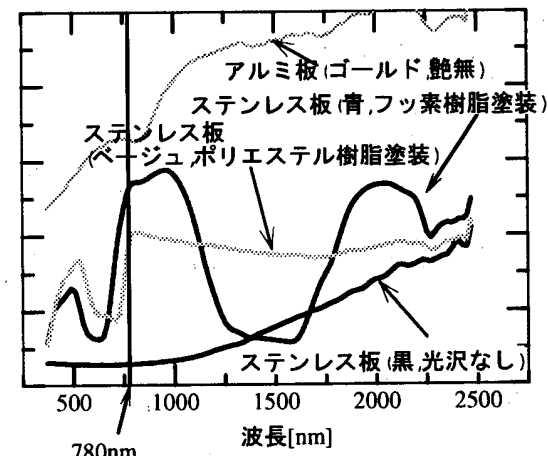

(b) 金属板

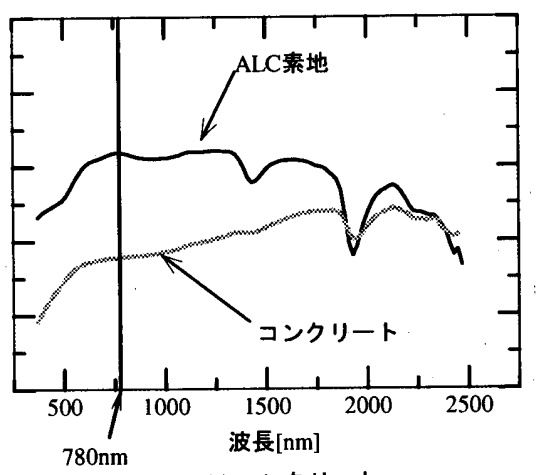

(e) コンクリート

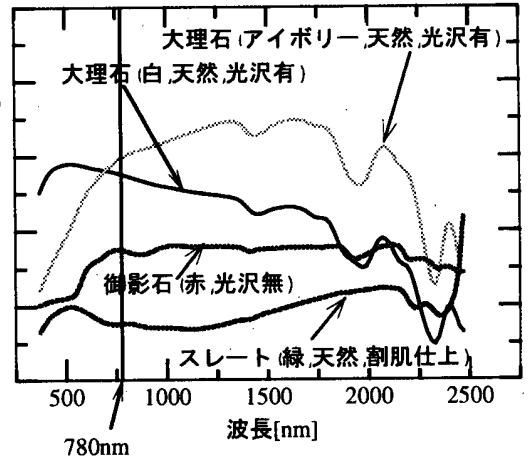

(c) 石材

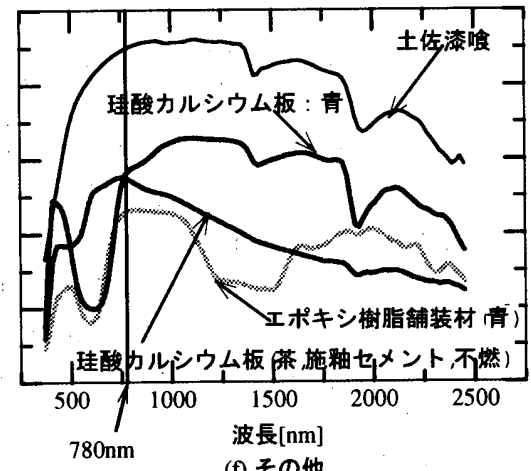

(f) その他

図 7 種類別の代表的な建材の分光反射率（入射角 $\mathbf{4 5}^{\circ}$ 時の半球樻分值）

で評価できるといえる，図 7 や表 4 は, 本論文で対象とした建 材試料を具体的な数值として示したものであるが, 汎用的に扱 うにはより多くの建材デー夕を集積する必要がある。

$$
\begin{gathered}
\rho=I_{U V+V} / I \cdot \rho_{U V+V} S T D+I_{N I R} / I \cdot \rho_{N I R} S T D(6) \\
\rho / \rho^{S T D}=1.79\left(\rho_{N I R}{ }^{S T D} / \rho^{S T D}-1\right)\left(I_{N I R} / I-0.44\right)+1
\end{gathered}
$$

\begin{tabular}{|c|c|c|c|c|}
\hline 分類 & 種類：色 & $\mathrm{UV}+\mathrm{V}$ & NIR & $\overline{A L L}$ \\
\hline \multirow[t]{3}{*}{ 多イル系 } & レンガ & 0.18 & 0.53 & 0.34 \\
\hline & 外壁夕イル：菳 & 0.23 & 0.38 & 0.30 \\
\hline & 外壁タイル：クレ & 0.25 & 0.36 & 0.30 \\
\hline \multirow[t]{4}{*}{ 金属板 } & アルミ板：コールト & 0.59 & 0.83 & 0.70 \\
\hline & ステンレス板：青 & 0.23 & 0.41 & 0.31 \\
\hline & ステンレス板：ベージュ & 0.25 & 0.38 & 0.31 \\
\hline & ステンレス板：黑 & 0.06 & 0.11 & 0.08 \\
\hline \multirow[t]{4}{*}{ 石材 } & 大理石：白 & 0.57 & 0.49 & 0.53 \\
\hline & 天理石：アイ末リー & 0.45 & 0.64 & 0.53 \\
\hline & 御影石：赤 & 0.27 & 0.35 & 0.31 \\
\hline & スレート：緑 & 0.18 & 0.16 & 0.17 \\
\hline \multirow[t]{5}{*}{ 淕装系 } & 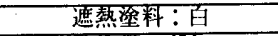 & 0.95 & 0.93 & 0.94 \\
\hline & 遮䂑坴料：ラレ- & 0.16 & 0.57 & 0.34 \\
\hline & 遮䱉淕料：青 & 0.10 & 0.56 & 0.31 \\
\hline & ウレダンコ㴔装：白 & 0.91 & 0.91 & 0.91 \\
\hline & ウレタンコム塗装：タレー & 0.24 & 0.19 & 0.21 \\
\hline \multirow[t]{2}{*}{ コンクリート } & ALC 素地 & 0.56 & 0.62 & 0.59 \\
\hline & コンクリート & 0.31 & 0.40 & 0.35 \\
\hline \multirow[t]{4}{*}{ その他 } & 樹脂系舗装材：青 & 0.25 & 0.39 & 0.32 \\
\hline & 理酸カルシウム板：青 & 0.31 & 0.59 & 0.43 \\
\hline & 理酸カルシウム板：茶 & 0.41 & 0.43 & 0.42 \\
\hline & 㵞喰 & 0.73 & 0.88 & 0.80 \\
\hline
\end{tabular}

表 4 代表的な市販建材の基準太陽光に対する波長帯別の日射反射率

5 まとめ

1. ガラスメーカー提供の分光データを元に算出した $\eta$ 值の 分光感度解析から, 波長選択性の高い高性能なガラスほど
入射日射の分光分布による偏差が大きく，直達・拡散日射 および太陽高度の高低といった変化に対して, 従来の単一 の $\eta$ 值では熱負荷計算などにおいて無視できない誤差が生 じ得ることがわかった。

2. 市販建材の分光反射率の測定結果から, 近赤外域での反 射率が高くなるものが多いことがわかった．特にタイル， 金属板や遮熱塗料でその傾向は顕著であった．測定デー夕 を元に算出した日射反射率の分光感度解析から, 波長選択 性の高い遮熱塗料では日射の状態によって, 従来の単一の 日射反射率の指標が大きな誤差要因となることがわかった.

3. 建材が有する分光特性と日射の分光特性を紫外可視光 域:UV+V と近赤外域:NIR の 2 波長帯によって簡易的に 扱い，代表的な数種類の分光日射での精算値との比較を行 なった結果から, 詳細な波長毎の評価を行わなくても 2 波 長帯による評価によって日射および建材の分光特性を概ね 反映できることがわかった。

4. 紫外可視光域と近赤外域における建材物性值の分光特性 と，日射の分光特性から，波長毎の精算值を得られる近似 式を示した。本論文で扱った建材試料の解析結果による回 帰式と近似式の係数は近い值であったが，この近似式をあ らゆる建材に適用できるかについては, より多くの試料を 用いた検証が必要である。また，本論文で扱った建材試料 の波長帯別の物性值を示したが, これらについても今後よ り多くのデータ蓄積が必要である。

【注記】

注 1) 本論文で波長带を 2 つに分ける波長を $780 \mathrm{~nm}$ とした理由は, 日射の 2 波長帯モデル化 ${ }^{9)}$ という面では, 水蒸気による吸収が

$780 \mathrm{~nm}$ 以下で殆ど無視できること, 日射のレイリー散乱の影響が近 赤外域で殆ど無くなること，大気圈外の日射エネルギーが $780 \mathrm{~nm}$ で約半分 (55:45) に分けられることなどから日射のモデル化が容易 であるためである．建材㑡では， $780 \mathrm{~nm}$ が可梘光域の終端であるた 
めである.また, ASHRAE Fundamentals $\left.{ }^{8}\right)$ において，ガラスの 物性値を 2 波長帯で扱う概念の記述がある.

注 2）ガラスの分光透過反射率の計測方法および使用した分光測光 器は JIS R 3106 ${ }^{2}$ ) による規定 (波長範囲：300-2500nm, 分解能： $5-50 \mathrm{~nm}$, 測光精度：測光值の正確さは最大目盛りの $1-2 \%$ 以下で繼 ク返し精度は 0.5-1\%以下，波長精度：波長目盛りの偏りは分光器の 透過波長带域の中心波長から $1-5 \mathrm{~nm}$ ，これらの条件を満たした分光 光度計に受光用の積分球を付属した分光測光器を用い, 透過率は入 射角 $0^{\circ}$ にて空気のみとの比較，反射率は入射角 $15^{\circ}$ 以内にて標準 試料との比較によって計測)に従ったものである.

注 3）晴天日における紫外可視光域および近赤外域の波長帯別の日 射量については，永田によって近似式が示されている ${ }^{9)}$.

注 4) 波長選択性を表す指標として佐野による熱光比 ${ }^{10}$ ) (二可視光 透過率 $/ \eta$ 值)による検討も行ったが，相関性が低くなった。ここで は 2 波長带による評価の精度を検討することを目的としているので, より相関性が高かった $\eta_{\mathrm{UV}+\mathrm{V}}^{\mathrm{STD}} / \eta^{\mathrm{STD}}$ を指標とした

注 5）板ガラスの分光反射・透過率の測定方法として JIS R $3106^{2}$ に記述されている積分球を用いた計測方法があるが，搪散性の高い 材料の測定方法は確立されていないと云われている11). 本論文で は図 A-1 に示す入射角と反射角を任意に設定可能な計測台を用い て, 入射角 $45^{\circ}$ における反射輝度の分布を入射面内について 18 点 計測し，式 (A-1)により算出した単位立体角あたりの反射率 $\rho\left(\theta_{\mathrm{I}} ; \theta_{\mathrm{R}}, \phi_{\mathrm{R}}\right)[1 / \mathrm{sr}]$ の角度分布について, 拡散反射成分と指向反射 成分への分離㧍よび関数化を牧野ら 12) による方法で行ない，式 (A-2)による半球方向への皘分で半球反射率を算出した。 なお，建 材表面の反射指向特性は入射角によって大きく変化するが，本論文 は波長特性に関する感度解析という位置付けであるので角度特性に ついては扱っていない．また，入射角は $45^{\circ}$ として測定しているが， 建材の分光反射特性に大きく影響する拡散反射成分は入射角による 変化は少ないので, 本論文の検討において問題ないと判断した。

$$
\begin{aligned}
& \rho\left(\theta_{I} ; \theta_{R}, \phi_{R}\right)=R D\left(\theta_{R}, \phi_{R}\right) / I\left(\theta_{I}\right) \\
& \rho\left(\theta_{I}\right)=\int_{-\pi}^{\pi} \int_{0}^{\pi / 2} \rho\left(\theta_{I} ; \theta_{R}, \phi_{R}\right) \cos \theta_{R} \sin \theta_{R} d \theta_{R} d \phi_{R} \quad(\mathrm{~A}-2) \\
& \text { ここで, } \\
& R D\left(\theta_{R}, \phi_{R}\right) \text { : 反射放射輝度測定値 }\left[\mathrm{W} /\left(\mathrm{m}^{2} \cdot \mathrm{sr}\right)\right] \\
& I\left(\theta_{I}\right) \quad: \text { 光源加試料面への入射放射照度 }\left[\mathrm{W} / \mathrm{m}^{2}\right]
\end{aligned}
$$
(白色標準板の反射輝度測定値から算出)

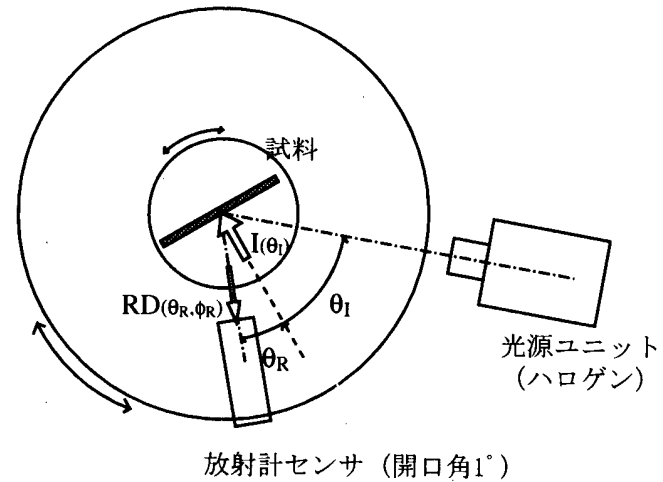

図A-1 反射率角度分布の測定装置

注 6) 本論文では，文献 12）を参考に正反射方向から前後 $5^{\circ}$ 以内 は $2.5^{\circ}$ 刻み, $15^{\circ}$ 以内は $5^{\circ}$ 刻み, それ以外は $5-15^{\circ}$ 刻みと, 指向 特性のピークが生じる正反射方向付近の計測点数を細かくして計 18 点としたが, 計測点数を 30 点とした場合と比較したところ，18 点 の場合と比べて半球反射率で高々 $2 \%$ 以内の差であった。 また，測定 は入射面内のみであるが，図 A-2 に示すように等方散乱を仮定した 反射モデルとの相関性がよいことから，入射面外の反射成分を測定 していないことに起因する誤差は小さいものと判断した。 また，計 測の再現性について 5 回の試行を行ったところ，半球反射率で $1 \%$ 程度の誤差（各波長について変動係数で確認）であったことから 再現性について問題はないと判断した。 また，分光放射計の精度は ガラスの測定についての JIS R 31062）の基準と同等の性能を有し ており，測光精度についても問題はないと判断した。

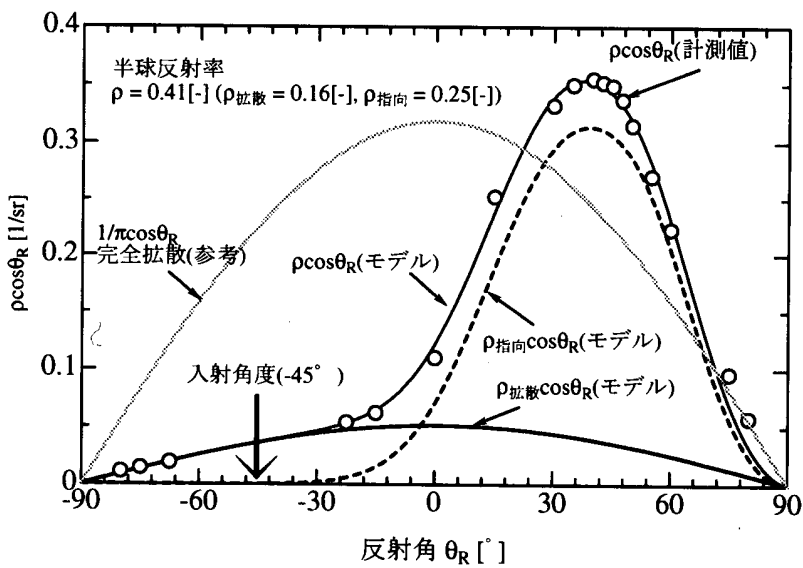

図A-2 反射率角度分布の測定値とモデルによる関数化

(入射面内 $\left.\phi_{\mathrm{R}}=0^{\circ}\right)$

【謝辞】

旭硝子 (株) からガラスの分光データの提供を, 工学院大学野部達 夫助教授から漆喰など伝統建材の利用を，また，多数の建材メー カーから建材サンプルの提供を得た。ここに記して謝意を表します。

【参考文献】

1）宿谷昌則：数値計算で学ぶ光と熱の建築環境学, pp.167-173，丸 善, 1993 年

2) 日本規格協会：JIS R 3106：1998 板ガラス類の透過率・反射 率・放射率・日射熱取得率の試験方法

3) W.Ross McCluney, Sensitivity of Fenestration Solar Gain to Source Spectrum and Angle of Incidence, ASHRAE Transactions, Vol.102 Part2, pp.112-122, 1996

4) 成田千恵, 田辺新一, 尾関義一，小西正哲：日射の波長特性が温 熱感に与える影響に関する研究，日本建築学会計画系論文報告集 第 545 号, pp.29-35, 2001 年 7 月

5）一八瀬雅之, 石野久彌, 永田明寛 : 建材表面の日射反射率におけ る分光感度特性, 日本建筑学会大会学術講演梗概集 D2, pp.373374,2003 年 9 月

6) 一八瀬雅之, 石野久彌, 永田明寛, 松本光代 : 空システムの分光 感度特性と配光特性に関する研究, 空気調和・衛生工学会学術講 演会講演論文集, pp.21-24, 2003 年 9 月

7) Richard E. Bird, A Simple, Solar Spectral Model for DirectNormal and Diffuse Horizontal Irradiance, Solar Energy, Vol.32 No.4, pp.461-471, 1984

8) ASHRAE. 2001. 2001 ASHRAE handbook - Fundamentals, 30.21 - 25, Atlanta: American Society of Heating, Refrigerating and Air-Conditioning Engineers, Inc.

9）永田明寞：2 波長域に分けた日射量近似モデル，日本建築学会大 会学術講演梗概集 D2, pp.49-50,2003 年 9 月

10）佐野武仁：膜構造建築に用いる塩ビ膜とフッ素樹脂膜の光特性 と熱特性に関する実験研究, 日本建築学会計画系論文報告集 第 451 号, pp.19-27, 1993 年 9 月

11）石積広行, 倉山千春, 上乗正信, 斉藤栄亮 : 開口部構成部材の光 学特性その 1 フレーム部における光学性能の測定及び色に上る 分類, 日本建築学会大会学術講演梗概集 D2, pp.369-370, 2003 年 9 月

12）牧野俊郎, 中村彰成, 若林英信 : 金属のあらい表面におけるふく 射反射の角度特性とその伝熱パラメー夕表現, 日本機械学会論文 集 (B 編) 65 巻 630 号, pp.324-330, 1999 年 2 月

(2003年11月 7 日原稿受理，2004年 5 月11日採用決定) 